when he concludes his articles he will have presented to the people of Iowa one of the proudest military records that adorn her history.

Dr. Salter's article is most appropriately accompanied by a portrait of General O. O. Howard, and two facsimiles of interesting manuscripts. One of the latter is General Corse's famous reply to the rebel General French's demand for the surrender of the fort, "to prevent the useless effusion of blood;" and the other the congratulatory order of General Howard upon the brilliant and heroic defense of Allatoona. These documents in the hand-writing of Generals Corse and Howard belong to the Aldrich Collection in the Historical Department of Iowa.

Since the foregoing was written the Historical Department has secured two very fine photographs of General Corse, in the uniform of a Major-General. The negatives were made many years ago by Brady, who was the leading early photographer of New York and Washington. One is in standing and the other in sitting posture. We believe they are the most faithful likenesses of General Corse in existence, affording the best data yet discovered for his statue on the Iowa Soldier's' Monument, or for a life-size portrait in oil. Copies were at once ordered by the Monument Commission. These negatives had passed into other ownership and were practically forgotten, until a lucky accident brought them to light.

\title{
A CHARACTERISTIC ORDER OF GENERAL SCOTT.
}

In the year 1890 the widow of General A. C. Dodge, one of our first United States Senators, presented to the a utograph collection, then in the Iowa State Library, the order book which General Henry Dodge kept. while in the military service. It is especially full and complete during the Black Hawk War. The book is a folio volume of 
some 400 pages of unruled paper, about half of which is filled with the writing of General Dodge. It contains the orders which he received from. superior officers, his own orders to subordinates, and the official letters which he wrote between 1832 and 1836. Aside from this volume very little of the writing of General Dodge has come to light in these later years, when it has been much sought. He was the foremost of western border heroes, the man whom General Jackson would have appointed United States Marshal of South Carolinia had she gone into rebellion in 1832, the first Governor of Wisconsin Territory when the present State of Iowa was included within its borders, and one of the first United States Senators after Wisconsin was admitted to the Union. He remained in this latter position until after Iowa was admitted as a State, when his son General A. C. Dodge was elected as one of our Senators. The writer of this item remembers seeing both father and son in their seats as United States Senators in 1853. Their portraits, as well as that of General Jones of our State-who is still with us as a well-pre. served nonagenarian-appear in Healy's great painting of "Webster's reply to Hayne," now in Faneuil Hall, Boston.

We expect in the future to find in this very valuable old book many interesting things to be transferred to these pages, but for the present we only take the following characteristic and very interesting order by General Winfield Scott, who made such a determined effort as the first prohibitionist in the West:

Asst. Adj. Gex'l's. Office, Fort Ammstrong, Rock Islavd, August 28, 1832 .

Order No. 16.

1. The choler, has made its appearance on Rock Island. The two first cases were brought by mistake from Captain Ford's company of United States mounted rangers; one of these died yesterday, the other is convalescent. A second death occurred this morning in the hospital in Fort Armstrong. The man was of the 4 th Infuntry, and had been some' time there under treatment for debility. The 
ranger now convalescent was in the same hospital with him for sixteen hours before a cholera hospital could be established outside the camp and fort.

2. It is believed that all these men were of intemperate habits. The ranger who is dead, it is known, generated the disease within him by a fit of intoxication.

3. This disease having appeared among the rangers and on this island, all in commission are called upon to exert themselves to the utmost to stop the spread of the calamity.

4. Sobriety, cleanliness of person, cleanliness of camp and quarters, together with care in the preparation of the men's messes, are the grand preventatives. Nu neglect under these heads will be overlooked or tolerated.

5. In addition to the foregoing the senior surgeon present recommends the use of llannel shirts, flannel drawers, and woolen stockings; but the commanding general, who has seen much of disease, knows that it is intemperance, which in the present state of the atmosphere, generates and spreads the calamity, and that when once spread good and temperate men are likely to take the infection.

6. He therefore peremptorily commands that every soldier or ranger that shall be found drunk or sensibly intoxicated after the publication of this order be compelled, as soon as his strength will permit, to dig a grave at a suitable burying place, large onough for his own reception, as such grave cannot fail soon to be wanted for the drunken man himself, or some drunken companion.

7. This order is given, as well to serve for the punishment of drunkness, as to spare good temperate men the labor of digging graves for their worthless companions.

8. The sanitary regulations now in force respecting communications between the camp near the mouth of Rock river and other camps and posts in the neighborhood are revoked. Colonel Eustis, however, whose troops are perfectly free from cholera, will report to the commanding general whether he believes it for the safety of his command that these regulations should be renewed.

By order of Major-General ScotT, P. H. GarT, Assistant Adjutant-General.

\section{A PRO-SLAVERY LETTER BY JOHN C. CALHOUN.}

Persons born since the great civil war have little idea of the deep feeling which existed for so many years throughout this country, relating to human slavery. Two points especially gave rise to the bitterest acrimony. 
Copyright of Annals of Iowa is the property of State of Iowa, by \& through the State Historical Society of Iowa and its content may not be copied or emailed to multiple sites or posted to a listserv without the copyright holder's express written permission. However, users may print, download, or email articles for individual use. 